\title{
Examination Preparation or Effective Teaching: Conflicting Priorities in the Implementation of a Pedagogic Innovation
}

\begin{abstract}
Communicative and task-based teaching hold central places in contemporary language pedagogy, yet their feasibility as pedagogic innovations in Chinese contexts remains open to question. Examinations are generally perceived as a particular factor militating against the implementation of communicative approaches. This study uses four case studies of teachers in two primary schools in China to provide in-depth empirical data, drawn from 55 lesson observations and a series of related interviews, focusing on the impact of examinations on classroom pedagogy. The analysis suggests that the influence of examinations differs from individual to individual, depending on various contextual and participant factors including teachers' beliefs about pedagogy. Implications for the relationship between pedagogic innovations and examination preparation are discussed.
\end{abstract}

\section{INTRODUCTION}

As China increases participation in the globalizing world, the development of English proficiency has become a major priority (Jin \& Cortazzi, 2002; Zheng \& Davison, 2008). In order to encourage communicative competence the Chinese government has, from the 1980s onwards, introduced various attempts to promote communicative language teaching, hereafter CLT (e.g. Li, 1984; Wang, 2007). CLT stresses the importance of providing learners with opportunities to use English for communicative purposes (Howatt, 1984). CLT in China has not been widely implemented, due to various contextual factors. Two challenges particularly relevant to the current paper are the potential conflict with educational norms and traditional teacher roles $(\mathrm{Hu}$, 2002, 2005a); and perceived incompatibility with the demands of high-stakes assessment (Littlewood, 2007; Qi, 2007).

The New National Curriculum Innovation (hereafter New Curriculum) launched in 2001 represented the first time that an English curriculum was introduced into China's primary schools on a nationwide level (Wang, 2007). Task-based language teaching (TBLT), an approach under the umbrella of CLT, was advocated as part of this curriculum (Hu, 2005b). The rationale for using TBLT is that students learn the target language more effectively when they are involved in meaningful communicative activities, rather than focusing on studying or manipulating grammatical rules (Ellis, 2003). TBLT in China faces similar implementation challenges to CLT. Zhang (2005), for example, found that although teachers claimed to be carrying out TBLT, few communicative activities were observable in classrooms.

Top-down introduction of communicative or task-based approaches is a feature of policy development within the East Asian region (Nunan, 2003). Government mandated pedagogic innovations, however, seldom impact on classrooms in the ways that administrators intend (Wedell, 2009). A common feature is government rhetoric, not backed up by adequate support or resources at the grass-roots level. This seems to 
carry resonance in China, where the thrust of educational reform has been at a policy level rather than in relation to classroom practice (Leung, 1991; Turner \& Acker, 2002) and there is a pressing need to see how innovation is enacted in the classroom; particularly at the primary school level where there is a dearth of research.

One of the reasons for lack of implementation of pedagogic innovations is the failure to account adequately for various contextual factors, one of which is the prevailing examination system. An examination-oriented culture is firmly embedded in China (Qi, 2005, 2007) and other Confucian-heritage contexts. In those contexts where examination-oriented education dominates, test formats are likely to have a greater influence on pedagogy than the latest government exhortations.

This paper arises from a study which examined the communicativeness of teaching in selected classrooms. A key finding was that teacher perceptions of examinations were a major factor influencing classroom practice and accordingly this paper has two aims:

- To consider how the relationship between examinations and classroom pedagogy is interpreted by four case study teachers;

- To analyze the role of examinations as a constraint to the implementation of a task-based innovation.

Its significance lies in its exploration of examinations as a potential inhibiting factor to the implementation of TBLT by using in-depth qualitative data collected through case studies of four primary school teachers in two different schools: one a regular state school and the other an experimental school. An analysis of this phenomenon also carries value beyond the immediate context in which it is researched.

In the coming sections, we first discuss the role of examinations as a factor constraining the implementation of communicative approaches. Then we describe the research methodology. In the findings section, we report classroom episodes and participants' viewpoints on the influence of examinations. Lastly, we analyse the relationship between communicative teaching and examination preparation, and sketch some issues for further exploration.

\section{EXAMINATIONS AS A POTENTIAL CONSTRAINT TO INNOVATIONS}

The framework for the paper is that the relationship of assessment to classroom practice involves a complex interplay of teacher values and beliefs on the one hand, and examination requirements and teachers' interpretations of them on the other. The basis for the framework is built up by interpreting selected aspects of the literature from international contexts, China and elsewhere in East Asia.

All assessment potentially has intended or unintended consequences and exerts great power on what goes on in the classroom (Shohamy, 2001). Washback studies examine the influence of testing on teaching and learning, for example, test reforms which are used purposefully as a lever to engineer pedagogic change (Cheng \& Curtis, 2004). Washback has been found to be a complex phenomenon which involves the interplay of numerous factors, including teacher understanding of the test and 
contextual factors, such as, available resources or classroom conditions (Wall, 2000).

In their seminal Sri Lankan study, Wall and Alderson (1993) analyzed the impact of a new examination, by which the government aimed to promote a more communicative approach. They found that whilst there was impact on the content of teaching, no evidence was found for any influence of the test on how teachers taught. In terms of teacher response, Burrows (2004) found that assessment impacted on teachers in different ways and it was suggested that teachers' personal beliefs, assumptions and knowledge should be taken into central consideration to explain why teachers responded to assessment reform differently. Both of these studies also revealed that teachers sometimes reported doing something because of a test, but that this action was not always consistent with its actual nature. Teachers' perceptions of an examination can be as significant as the test itself.

Systems of public assessment usually fail to keep pace with other developments in the curriculum (Littlewood, 2007). A repercussion is that examinations often act as a factor impeding the implementation of pedagogic innovations ( $\mathrm{Li}, 1998$; Wedell, 2009). Recently, there have been attempts within the Asia-Pacific region to change the content or format of high-stakes examinations so as to align assessments with communicative syllabi, hoping to stimulate changes in pedagogy. In China, the NMET (the National Matriculation English Test) used for university entrance purposes has been modified with an intention to promote writing with communicative purposes. Qi (2007), however, found that teachers still mainly adopted traditional methods to teach writing and tended to ignore the intention of the NMET setters. Teachers' beliefs and experiences in language teaching were found to be one of the contributing factors (Qi, 2005). Another factor is that the status of teachers in China is very much related to the test scores achieved by their students (Cheng \& Qi, 2006). CLT is not interpreted as being congruent with these examination demands. In an evocative phrase, CLT is viewed as producing students who 'speak loud in class but scratch their heads in tests and exams' (Ouyang, 2000, p. 410).

The situation in neighboring settings also carries resonance for the current paper. In Japan, grammar-translation seems to be firmly embedded in the instructional practices of teachers, and is often justified by teachers in terms of the needs of university entrance examinations (Samimy \& Kobayashi, 2004). On the basis of a study using classroom observations and interviews with teachers, Watanabe $(1996,2004)$ suggests, however, that teacher factors, such as educational background, personal beliefs and teaching experience may outweigh the effect of examinations. Reinforcing this is that once an educational practice is accepted as a societal tradition, it becomes the educational norm (O’Donnell, 2005), and hence difficult to shift.

Also of relevance to the relationship between examinations and pedagogy are recent developments in Hong Kong. Unsuccessful early attempts to implement CLT raised awareness of the need to align pedagogy and examinations formats (e.g. Evans, 1996). Following from this, governmental agencies have tried to engineer changes in pedagogy via modifications to assessment (Cheng, 1999; Davison, 2007). For example, in 1996, changes to the Hong Kong Certificate of Education Examination (HKCEE) oral examination including role-play and group discussion were adopted to 
stimulate implementation of CLT. In her washback study, Cheng (1999), however, found that teachers still mainly used traditional methods to prepare students for the examinations and very little change was found in teachers' pedagogical philosophy. More recently, a further school-based oral assessment has been incorporated into HKCEE requiring students to carry out communicative speaking tasks in their own schools, with these counting towards their final external examination grade (Davison, 2007; Luk, 2010). Yet many teachers still report examinations as a constraint to the implementation of TBLT and teacher beliefs about pedagogy and assessment seem to be more of a barrier to the TBLT innovation than the actual mode of examinations (Carless, 2007).

Not all of the studies cited here have involved in-depth classroom observation, supplemented by interview data facilitating interpretation of classroom processes and impact of teacher beliefs. The need for more classroom-based observation and analysis of the interplay between innovation and examinations underpins the current study.

\section{THE STUDY}

\section{Context}

This study was conducted in Nanhai District, Guangdong. This site was chosen because of the first author's contacts and prior working experience there. The New Curriculum was introduced in Nanhai in 2003. New textbooks have been adopted, which are claimed to be compatible with TBLT and some one-off mass-lecture training seminars were provided. Although TBLT is recommended in the New Curriculum (PEP, 2001), key concepts are not clearly defined and concrete implementation suggestions are not provided (Zhang, 2005). Local schools in Nanhai are encouraged to try out the new curriculum according to their own understanding and interpretations. Under the general spirit of the new curriculum, numerous different pedagogic concepts are discussed by individual schools, suggesting a broad view of CLT. The relationship between the various concepts, however, is not clearly articulated with TBLT.

Assessment in Nanhai primary schools is stated officially to be low-stakes because the allocation to state junior high schools is based on students' hukou (household registration) rather than entrance examinations. In reality, however, examinations are interpreted by school personnel, students and parents as high-stakes because of ranking systems conducted by the Education Office (EO) seen as important criteria to evaluate the quality of schools and teachers. External public examinations in English, from Year 4 to 6, are set by the EO each semester. No feedback other than raw scores is provided by the EO after the examinations. English examinations from Year 1 to 3 are less high-stakes because students in these grades take internal examinations instead. For confidentiality purposes, internal examinations are set by English subject colleagues in the school who are not teaching that specific year level. In other words, the subject teachers have no role in setting examination papers for their own class and do not see the examination paper before it is administered. In addition to the end of 
semester external (Year 4-6) and internal examinations (Year 1-3), students also take monthly unit quizzes set by the EO. Unit quiz results are not submitted to the EO, but they are used by school principals as a criterion to evaluate the quality of teacher's regular teaching. All examinations include listening and written tests without oral components. Items are generally not task-based with emphasis on traditional testing formats focused mainly on assessing vocabulary and grammar knowledge. Common test types include multiple-choice, cloze, true or false and reading comprehension.

\section{Case Schools and Teachers}

The study involves 4 teachers from 2 primary schools chosen on the basis of purposive sampling (Patton, 1990). The selection of schools was facilitated by the EO and five schools showed interest in participating. After conducting a thorough pilot study, two schools were selected based on the supportiveness of the school principals and the fact that teachers and students in both schools were accustomed to being observed, and so less likely to be affected by the presence of a researcher. We also selected different school types: a state school and an experimental school. State schools are owned, funded and managed by the government. They follow the mandated curriculum quite rigidly under the guidelines of the EO. Experimental schools are private schools with better conditions, diverse curricula and generally more experienced teachers. School A is a state school located in an urban area with students coming from middle-class backgrounds. It shares similar characteristics with other state schools in this district. English study begins in Year 3 as per national policy. School B is a reputed "English-featured" experimental school with a high standard of examination results. English education begins in this school in Year 1. Although School B enjoys more autonomy than state schools, it is still under general supervision of the EO, which means the two case schools are under the same examination system. The dual case approach is a suitable strategy for this study because it allows us to probe in-depth, whilst also analyzing variation between two contrasting schools.

The teachers were recommended by the school principals as being suitable for a study on the implementation of communicative teaching: we felt this was an important aspect of the sampling given that the literature reviewed earlier had highlighted the difficulties of implementing CLT or TBLT in China. Although selecting a sample in this way has its limitations, we felt that the purposive selection of teachers with potential to implement TBLT was the most effective way of advancing the objectives of our research. In terms of teachers' education background, Betty and Jane were English specialists whilst Rose and Paul were not. Nonspecialists being required to teach English occurs frequently because of the shortage of teachers in Nanhai (and elsewhere in China). The background of the teachers is summarized in Table I.

Table I. Case teachers

\begin{tabular}{llllll}
\hline Teacher & School type & Education & Teaching & Lessons per week in & Year Level \\
\hline
\end{tabular}




\begin{tabular}{llllll}
\hline & & background & experience & the observed class & \\
\hline Betty & $\begin{array}{l}\text { State school } \\
\text { (School A) }\end{array}$ & specialist & 20 years & 3 lessons & Year 3 \\
Rose & non-specialist & 3 years & 4 lessons & Year 4 \\
\hline Paul & $\begin{array}{l}\text { Experimental } \\
\text { school } \\
\text { Jane }\end{array}$ & non-specialist & 16 years & 7 lessons & Year 4 \\
\hline
\end{tabular}

Research procedures

Two interlinked research questions guide this paper:

RQ1 How do four case study teachers perceive the relationship between examinations and classroom pedagogy?

RQ2 To what extent and how do teachers perceive examinations as inhibiting the implementation of communicative activities?

The research involved a qualitative case study approach. The research methods are classroom observations and interviews. A total of 55 video-taped lesson observations were spread equally between the four teachers. Lessons in both schools are of 40 minutes duration. Sequences of lessons were observed so as to uncover how a topic unfolded and the kinds of classroom activities being carried out. These lessons were observed in the first three months of a semester and the final examinations were two months later. In other words, the observations were of regular lessons during the semester which did not directly precede examinations.

A tool we used to facilitate our analysis of classroom events was the wellrecognized communicative continuum proposed by Littlewood (2004). This framework denotes activities as belonging to five categories, ranging from noncommunicative learning on the left-hand side of the continuum through a mid-point of communicative language practice to authentic communication on the extreme right. A key dimension of the continuum is the extent to which new communicative information is transmitted in an activity; this is represented by the mid-point or third category. Charting the activities observed in the classrooms on the continuum provided data to indicate the communicativeness of classroom teaching (see also Deng \& Carless, 2009). In the findings section, we present the percentages of activities in each category of Littlewood's continuum in order to facilitate comparison of the communicativeness of the lessons amongst the four participants.

To aid our interpretation of classroom events, twelve individual interviews were carried out with each teacher participant, comprising baseline interviews, a series of post-lesson interviews and a concluding reflective discussion. Interviews, of 40 to 60 minutes duration carried out within two days after the specific classroom observations, focused mainly on teachers' rationale for classroom activities, their relationship with TBLT and their perceptions of key pedagogic issues arising. In later interviews, one of the main foci was to explore in more depth emerging themes from the preliminary data analysis. Student focus groups of 6-10 students were interviewed after lessons in order to gauge their perceptions of classroom events for the purpose of triangulation 
with the teacher data. A limitation of the student data is that few critical comments were made. We also interviewed the English coordinators in both schools; the principal in School A and the vice principal, who oversees English teaching, in School B; these data are used to reflect relevant views of school decision-makers. All interviews were conducted in Chinese, audio-taped, transcribed and then translated into English with selected verification carried out by another bi-lingual researcher.

Data analysis

Data analysis was carried out according to the principles of inductive analysis, based on procedures set out in Miles and Huberman (1994). After fully transcribing the lesson recordings and interviews, we repeatedly studied all the raw data relevant to the theme of examinations and segmented them according to the research questions. We assigned codes (e.g. teachers' beliefs, teachers' views on examinations, examination-related teaching) to relevant observational and interview data to facilitate cross-case analysis. Through an iterative process, we established how and why examinations impacted on the classroom teaching of the four teachers in the two schools. We synthesized and summarized our emerging loosely-structured ideas and condensed them into arguments using all data relevant to the theme of examinations. To enhance the trustworthiness of findings, we triangulated between different data sets and used member checking (Erlandson, Harris, Skipper \& Allen, 1993), whereby the teachers responded to emerging propositions which were then revised accordingly. In particular, we used the member checking stage to clarify points of ambiguity in the data and to check our interpretations of classroom events.

\section{FINDINGS}

The findings are divided into sub-sections which focus respectively on the two schools. We include one classroom example from each of the four teachers to illustrate key points relevant to the discussion, using quotations from participants to provide their perceptions of these classroom events.

School A: State School

The principal in school A, a mathematics specialist, provided some views on the New Curriculum as follows: "Innovative approaches sound good, but I think traditional approaches could be more helpful within the traditional examination system." She expressed the view that the school was experiencing some pressure emanating from the external public examinations because it had been losing its position in the school rankings. The principal perceived that the school needed to restore its reputation for high academic standards through good examination results.

The school English coordinator reported that the school focus for English teachers 
was on "rich input teaching" and "group study" approaches. The relationship between these notions and TBLT was not clarified. The coordinator commented that teachers did not have sufficient knowledge about these methods due to a lack of training, but were encouraged to try them out. A further feature of the school was a mandatory policy to increase teaching time on examination preparation. According to this policy, teachers should spend no less than 15 minutes on a commercial workbook, which focuses on grammar exercises with similar items to the final examinations. In addition to this workbook, teachers also set some grammar-focused worksheets before a unit quiz. The observation data confirmed that Betty and Rose did both spend from 10-25 minutes on these exam-related exercises in almost all observed lessons.

By applying Littlewood's communicative continuum to the activities used in the observed lessons, we indicate the communicativeness of lessons (see Table II below). Non-communicative learning in the table refers to a focus on the structures of language without attention to meaning; pre-communicative practice denotes activities such as question and answer with some attention to meaning but not communicating new information; communicative practice involves pre-taught language where it communicates new information,; structured communication extends the previous category to include some unpredictability; and authentic communication further increases the complexity and unpredictability of language use(Littlewood, 2004).

By adhering closely to Littlewood's categories and related commentary a high degree of agreement was reached between us regarding in which category a particular activity should be placed. When conflicting viewpoints occurred, we debated them and reached a consensus.

Table II.The communicativeness of classroom activities in School A

\begin{tabular}{|l|l|l|l|l|l|}
\hline $\begin{array}{l}\text { Communicative- } \\
\text { ness of activities }\end{array}$ & $\begin{array}{l}\text { Non- } \\
\text { communicative } \\
\text { learning }\end{array}$ & $\begin{array}{l}\text { Pre- } \\
\text { communicative } \\
\text { Practice }\end{array}$ & $\begin{array}{l}\text { Communicative } \\
\text { Practice }\end{array}$ & $\begin{array}{l}\text { Structured } \\
\text { Communication }\end{array}$ & $\begin{array}{l}\text { Authentic } \\
\text { communication }\end{array}$ \\
\hline Betty & $54.4 \%$ & $36.3 \%$ & $7 \%$ & $2.3 \%$ & Nil \\
\hline Rose & $74.1 \%$ & $22.9 \%$ & $3 \%$ & Nil & Nil \\
\hline
\end{tabular}

\section{Betty's teaching.}

Betty is an experienced English specialist, but not trained in CLT which was not a priority area when she graduated 20 years previously. She was teaching a Year 3 class at the time of the study. When asked about her teaching procedures, Betty stated:

The first step is to present the new language items clearly. I then drill students with mechanical repetition. I consolidate students’ grammar knowledge with exercises.

In interviews, Betty reported two factors which impact on her teaching: the principal and her own experience:

I use a lot of 'repeating one by one' activities because the principal thinks such activities involve more students in participation. From my own experience, TBLT seems to be difficult for regular teaching because task-based activities sometimes 
cause discipline problems.

We interpret that Betty seems to favor traditional pedagogies, including a focus on repetition. She commented on the role of examinations as follows:

Training my students to do exams forms an important part of my teaching. I cannot think of a better way to prepare my students for examinations, so I will do exam practice exercises.

Our interpretation is that using exam practice seems to be the 'assumed truth' she holds as an effective method for examination preparation. We provide an example from one of her lessons, involving the teaching of a chant. Betty reported that chant teaching was important because sentences in chants were often tested in examinations. Betty first explained the Chinese meaning of the relevant vocabulary and then asked the whole class to repeat the chant through a reading contest in groups. The chant was:

J, J, J, jump, jump, jump.

$\mathrm{K}, \mathrm{K}, \mathrm{K}$, kick, kick, kick.

L, L, L, la, la, la.

The general orientation of the students in the interviews was positive towards this activity. Below are two comments that reflect their views:

This chant is fun and it helps me to remember the letters.

If I memorize the chant, I can do the part in the exam.

Betty was also positive towards the process: "I am satisfied with this activity because my students memorized the chant through the reading contest”. In terms of communicativeness, it was mechanical and de-contextualized, suggesting a low degree of TBLT implementation.

During the post-lesson interview, we discussed a unit-quiz paper which related this chant with an item in the listening section of the test. The item required students to match a listening segment e.g. "L, L, L, la, la, la” with the appropriate picture i.e. a girl singing. Betty stated: "Most items need mechanical memorization such as this one. If my students can memorize the chant, they can get the right answer”.

Betty also mentioned pressure from internal and external examinations:

I worry that in our internal examinations our principal might compare us among colleagues. More importantly, I won't forget that my students are going to take part in the public examinations next year. I would like to train them earlier rather than later.

This quotation exemplifies pressure on teachers from the examination-oriented system and suggests that training students for future high-stakes examinations seems 
to be one of the rationales for emphasizing testing in the early years of schooling. In this sense, although examinations in primary schools may seem to be less high-stakes than at later stages of schooling, teachers may see an important role of examinations as preparing students for future competitive examinations.

\section{Rose's teaching.}

Rose is a non-English major, so has not received formal training in CLT or TBLT. She was teaching a Year 4 class. She expressed some of her beliefs about teaching as follows:

Mechanical repetition and imitation is a foundation of learning. It is naive to think that students can develop their abilities by using their limited English among themselves, unless they have first accumulated a certain amount of vocabulary and sentences through memorization.

With respect to TBLT, she commented as follows:

Due to the lack of training, I don't know how to implement TBLT in my class. I am not sure if students who are more willing to participate in oral activities can get higher marks.

We infer that Rose does not seem to have a positive attitude towards communicative pedagogies and a major orientation of her teaching is on imitation and practice. In one lesson we observed, Rose tried to implement a communicative activity which involved group discussion. Many of her students were off-task and talked loudly in the mother tongue. Rose decided to stop the discussion and replaced it with a written exercise. Rose further commented on the role of examinations and reported that the orientation of the principal contributed to her exam-oriented teaching:

Our principal highly values examinations. It doesn't matter what approach I use to teach a lesson unless I can help students get good marks in the examinations...Training students for examinations with exercise-related teaching is a tradition in our school. It is also an important part of my teaching.

One of our classroom observations concerned a lesson following a unit quiz in which Rose's stated aim was to consolidate student knowledge through explaining answers to students. Test items include "making the right response according to what you hear" in the listening section.

(Listening transcript: What are they?)
A. These are my pants.
B. This is my sweater. 
Rose read the transcript and asked students to make a choice from A and B. She then explained the answer in Chinese, with the grammatical element of subject-verb agreement indicating that $\mathrm{A}$ is the correct answer. The following excerpt shows how Rose explained the relevant grammar in the textbook.

T: Dakai 31 ye. Kandao 'my shirt is red' zhege juzi ma?

(Look at page 31. Can you find the sentence 'my shirt is red' ) ?

Ss: Yes.

T: Keyi shuo 'my shirt are red' ma?

(Can we say 'my shirt are red') ?

Ss: No response from the students.

T: Bukeyi zheme shuo, 'my shirt are red' shi cuoju. Weishenme?

(No, 'my shirt are red' is a wrong sentence. Do you know why? )

Ss: No response from the students.

T: Yinwei 'my shirt' shi danshu. Zheli buyao yong 'are'

(That's because 'my shirt' is singular. Don’t use 'are' here ).

Rose expressed some views about this activity:

I believe that explaining the answers after a test helps my students to consolidate the knowledge. I think that students with more exam-related training can do better than those with less training.

Diverse student perspectives were expressed. Many were positive about the examoriented exercises. For example, one student said: “Teacher's explanation helps me understand how to get right answers in the unit test and final examination". This perception seemed quite common among students. A small number of students expressed negative feelings, but they did not seem to oppose the philosophy of examrelating teaching. They dislike exam-related teaching because of affective reasons, such as having less enjoyment. For example, one student said: "Doing exercises or checking answers is not as fun as doing games or activities”.

Rose also reported that she felt more comfortable delivering a grammar-focused lesson than a communicative lesson because of her own modest English proficiency:

Compared with traditional teacher-centered activities, communicative open-ended activities make me feel insecure because I worry that my students might ask me something I cannot say in English due to my limited English proficiency.

Although most of the examination items were grammar or vocabulary-focused, there were still some items that need some communicative use of language. For example, there is an item called "answer the questions according to the real-life situation". However, rather than asking students to practice communicative English, Rose stated that one of the strategies to prepare students for this item was to 
memorize the possible answers before examinations. She believed that memorizing was a suitable preparation strategy for these kinds of items.

\section{Summary for school $A$.}

The two teachers in School A seemed to be more focused on examination preparation than the kinds of communicative activities implied in the New Curriculum. Both teachers commented on the important role of examinations in their teaching. Factors that cause this phenomenon are complex, including for example, influence of the principal and the school policy, the non-communicative nature of most examination items and some teacher-related factors such as lack of knowledge of, or confidence in, TBLT.

\section{School B: Experimental School}

The interview with the school vice-principal reveals that School B also experienced examination pressure, yet they aimed to enhance teaching quality by adopting innovative pedagogy. The vice principal is an experienced English specialist who has won several teaching awards. She worked closely with the English team and put forward some teaching guidelines. The advocated approaches were called story-telling teaching, topic-based teaching and task-based teaching. This school also provided some support by inviting local experts to give workshops about New Curriculum teaching. Jane and Paul claimed that they tried to implement features of these approaches. They also reported that they were in a more favorable situation than that of other schools because of factors, such as more advanced textbooks and extra time for English teaching (i.e. more lessons than in school A).

School B did not have mandatory time allocations for examination preparation teaching as in School A. Teachers stated that they only conducted exam-related teaching if they thought it was necessary. Paul reported that he would do more examrelated teaching before the final examination. Jane reported that her focus was on teaching rather than examination preparation.

The communicativeness of activities in observed lessons in school B is summarized below in Table III.

Table III. The communicativeness of classroom activities in School B

\begin{tabular}{|l|l|l|l|l|l|}
\hline $\begin{array}{l}\text { Communicative- } \\
\text { ness of activities }\end{array}$ & $\begin{array}{l}\text { Non- } \\
\text { communicative } \\
\text { learning }\end{array}$ & $\begin{array}{l}\text { Pre- } \\
\text { communicative } \\
\text { Practice }\end{array}$ & $\begin{array}{l}\text { Communicative } \\
\text { Practice }\end{array}$ & $\begin{array}{l}\text { Structured } \\
\text { Communication }\end{array}$ & $\begin{array}{l}\text { Authentic } \\
\text { communication }\end{array}$ \\
\hline Paul & $31.7 \%$ & $43.2 \%$ & $17.1 \%$ & $8.1 \%$ & Nil \\
\hline Jane & $29.6 \%$ & $31.4 \%$ & $31.5 \%$ & $7.5 \%$ & Nil \\
\hline
\end{tabular}

\section{Paul's teaching.}

Paul is a non-English major, so has not received formal training in TBLT. He was teaching a Year 4 class and described his general teaching procedure as follows: 
At the beginning of a lesson, I usually present new knowledge in a meaningful situation. Next step is to drill the target vocabulary and sentences. I then request students to use the language in some less controlled activities...We are encouraged by the school to use activities in meaningful contexts to help students acquire English proficiency. I try to follow this in my teaching.

Paul commented on the role of examinations:

Examinations are important to any teacher, but I don't want to be too examoriented because I think my students can perform well in tests if I teach them well in regular lessons and support them with some intensive exercise training before the examinations.

The following episode illustrates aspects of Paul's teaching. The language points are:

How many apples are there in the bag? There aren't many.

How much chalk is there in the box? There isn't much.

In this lesson, after some mechanical repetition, Paul used a guessing game, in which his students could use the target sentences. Here is an excerpt from the guessing game.

The teacher showed his wallet to the students and asked.

T: Please guess. How much money is there in my wallet?

S1: There is 500 Yuan.

$\mathrm{T}$ : The person who makes the right guess can have the money. Who wants to guess again?

S2: No money.

$\mathrm{T}$ : Do you mean that there isn't any money in the wallet?

S3: There is 10 cents.

T: Yes, you are right. There isn’t much money.

We found that guessing games were well-received by students. No negative comments were made. Some students expressed that they liked the enjoyment feature in guessing games. Some said that they learned well by participating in them. Others said that the unpredictability made guessing meaningful.

Paul then explained the grammatical difference between 'how many' and 'how much' in Chinese. In the next lesson, he devoted the entire lesson to form-focused written exercises, one of which was a 'correct the errors' exercise. One of the wrong sentences written on the blackboard was "How much people are there?"

$\mathrm{T}$ : What is wrong in this sentence?

S1: Yinggai yong 'many', bushi 'much'.

(We should use 'many' rather than 'much' in this sentence). 


\section{T: Why?}

S1: Yinwei 'people' shi keshu mingci.

(Because the noun 'people' is countable).

T: Good.

Paul explained his rationale for these activities:

In the guessing game, I wanted my students to use the target sentences to express themselves. I then explained the grammatical rules to help them understand better. Finally, I consolidated their knowledge with grammar-based exercises. Teaching without the last two steps would cause a problem in terms of the examinations.

Our classroom observations led us to conclude that although Paul mainly used traditional teaching strategies, he tried to integrate some communicative elements within his approach. Paul also reported that he noticed changes to the external public examinations. He commented as follows:

The external examination last semester was more difficult than usual. I feel a potential threat from other schools because they spend more time than us on examination preparation. This semester, I do more drilling for examinations and reduce some time on communicative activities.

The comment reflects the importance of teachers' perceptions of examinations. Since Paul sees the examinations as getting more difficult, he felt a need to reduce communicative teaching. Our interpretation, however, was that he had only a partial understanding of the examination and his perceptions of it were not necessarily based on accurate interpretations of the nature and purpose of the test.

\section{Jane's teaching.}

Jane is an English specialist, trained in communicative approaches. She was teaching a Year 2 class and her case tells a somewhat different story to that of Paul. She expressed her teaching belief and her views on the school culture as follows:

The target of my lessons is for students to understand English in a meaningful context, use English in an appropriate way and exchange thoughts using the target language...I am glad that our school provides us opportunities to learn new ways of teaching and I am willing to try them out.

Observation data indicate that Jane often created situations related to real-life in which students could use the target vocabulary or sentences. For instance, in a lesson about snacks and food, she created a picnic role-play as a context for students to use target vocabulary. In this lesson, her students acted the parts of animal characters. The

following excerpt is taken from the final presentation when participants acted out the 
story.

Four students volunteered to present their picnic story in front of the whole class.

S1: Look, we have a lot of food. What do you like, Rabbit?

S2: I like hamburger, Cat.

S1: Here you are.

S2: Thanks.

The teacher appeared, acting as a wolf.

T: I am a wolf. I am hungry. I want to eat. Do you have any food?

Students acted frightened. They then decided to recommend delicious food for the wolf so that he did not eat them.

S1: Hello, Wolf. Do you like hamburger?

T: Hamburger? No, it's not delicious.

S2: Apples are delicious. Do you like apples?

T: Apples? Really? No, I don't like apples.

S3: Hello, do you like bananas?

T: Are they delicious? I don't think so. I don't like bananas.

S4: Spaghetti is delicious. Do you like spaghetti?

T: Spaghetti? Yes, I like spaghetti. Thank you.

Ss: The students acted relieved when "the wolf" accepted the recommended food.

Students were asked for their opinions. Here are three examples:

The wolf story in today's lesson was really fun. It made me laugh.

I can learn a lot by participating in role plays.

I like role-plays but I didn't volunteer to perform the story today because I feel nervous speaking in public.

The above quotations represent two types of student opinions. Some students welcomed role plays and perceived them as enjoyable and helpful. Others, however, seemed to be less positive, with a typical concern being loss of face in front of peers as suggested by the third quotation.

In the post-lesson interview, Jane expressed her favorable orientation to this activity and expressed her rationale for using role-play as a strategy:

I am satisfied with the presentation of the story. Students made it even more interesting than I expected...I like students to participate in lessons by role plays because that gives them opportunities to use the language in a meaningful situation.

We interpret Jane as deploying some communicative elements, such as putting language into meaningful use through role-plays with a correspondingly reduced emphasis on examination preparation. Compared with the other teachers, Jane also used much less Chinese for explanation purpose although her students were in a lower year level.

Unlike the two teachers in school A and her colleague, Paul, in interviews Jane did 
not refer to the impact of examinations. We inferred from this that she did not perceive that examinations were an important factor impacting on her choice of pedagogy. In interviews conducted towards the end of the study, we wanted to find out why Jane perceived examinations as less of a constraint than the other three teachers, so we raised the issue directly. Here is her response:

I think my students can do well in exams because they have opportunities to use English in lessons. Besides, mechanical learning won't be very helpful in our internal examinations because if our students don't learn well, even if they can memorize things, they will still have problems using the language in the right situation.

We interpret that one of the reasons why Jane does not concern herself much about examinations is her confidence in effective communicative teaching. She also refers to a belief that communicative pedagogies are suitable preparation for school internal examinations, and she seems to put more emphasis on these tests rather than future external ones. The fact that she was teaching Year 2 rather than Year 4 as Paul did, may be one factor explaining why examinations play less of a role for her.

\section{Summary for school B.}

There were more communicative activities observable in school B (than in school A). Teachers tried to integrate communicative teaching with examination preparation and Jane implemented more communicative teaching than Paul. Factors that influence teacher's choice of approaches in this school include teachers' individual beliefs, pressure from external examinations and the year level that they are teaching.

\section{DISCUSSION}

This paper has explored ways in which examinations have acted as a constraint on the implementation of a communicative innovation. The influence of examinations varies according to contextual factors and teachers' responses. These factors include, for example, how teachers interpret examinations and their accountability dimensions; school differences and individual teachers' beliefs. Although at the outset of the study, we were uncertain whether examination pressure would be a major factor impacting on pedagogy in the primary school classroom at Years 2, 3 and 4, the evidence indicated that this was indeed the case. The onset of examination pressure at such a young age could be viewed as a worrying trend likely to increase the anxiety associated with foreign language learning; or alternatively, as its adherents might argue, it might be seen as a useful early preparation for a successful learning career in examination-oriented educational systems.

Teachers in this study all noticed some impetus towards a more communicative curriculum. Congruent with other washback studies (e.g. Wall \& Alderson, 1993; Watanabe, 2004), they tended, however, to mediate the intention of the change and 
react to it according to their personal philosophies towards language teaching and examinations. Betty and Rose generally put emphasis on repetition and memorization within a school policy stressing examination preparation. Paul perceived the new examinations as more difficult, and he associated this with a need to employ traditional teaching methods rather than communicative ones. Jane perceived some support in the school for innovative teaching methods and saw this as an opportunity to carry out communicative activities with her students. In sum, in relation to RQ1, the impact of examinations on classroom practice was perceived by Betty and Rose to be strong, by Paul to be present but modest, and Jane to be almost non-existent.

School differences are also found to be an important factor impacting on the interplay between communicative activities and examination preparation. School B in this study is identified as having a more favorable situation for TBLT implementation because it has richer resources, more English lessons and greater flexibility. The positive orientation of School B towards innovative methods encouraged Jane (and to a lesser extent, Paul) to focus more on communicative teaching than examination preparation. In contrast, School A values traditional teaching and has policies which mandate the amount of time allocated for examination preparation. This school examination-oriented culture, however, does not occur in vacuum but is rooted in particular contextual factors, for example, the accountability pressures derived from the spectre of a lower position in school rankings and associated loss of status. As Qi (2007) suggests, teaching to raise student examination scores is consistent with the widespread instrumental motivation for English language learning in China among different stakeholders, particularly school principals and parents.

In addition to the variation between the two schools, there are also differences among the teachers themselves. Jane's classroom activities and her pedagogical beliefs are found to be different from the other three teachers. For example, she was the only teacher who frequently used role-plays related to real-life. The interviews indicate that she has a more positive attitude and better understanding of TBLT than the other three teachers, partly because it shares some characteristics with her beliefs about language teaching and learning. One of the most pertinent issues in the study is the tension between effective communicative teaching and examination preparation. Jane seems to be less pressurized by examinations than the other teachers because she believes that if teachers teach effectively, then her learners can perform well in assessments. We speculate, however, that only a minority of teachers think like that in view of the the influence of accountability pressures emanating from school management and parents. Extending our scope beyond the current findings, it is possible that teachers in the Greater China Region tend to regard examination-related teaching as the primary means to prepare students for examinations.

To sum up with respect to RQ2, the two teachers in school A both saw examinations as strongly inhibiting communicative activities. In school B, Paul perceived that the examinations were becoming more difficult and that competition from other schools allowed him less time for communicative elements. Jane, on the other hand, felt that communicative teaching could provide an appropriate foundation for future examination success. 
Whilst traditional examinations are clearly a factor impeding the implementation of TBLT, we believe that teacher beliefs mediated through societal values are even more powerful factors. As Carless' (2007) study implies, even in a context like Hong Kong, where high-stakes examinations have moved in a more communicative direction for some years, teachers still seem to express a preference for preparing students for taskbased examinations with non-communicative means. This provides some support for Watanabe's (1996, 2004) argument that teacher factors are more significant than the specific details of an examination in constraining communicative pedagogies. In other words, it may be teachers' beliefs rather than the role of examinations that are a more powerful barrier to pedagogic innovation. Related to this, and reinforcing a point made in the washback literature (Burrows, 2004; Wall \& Anderson, 1993) is our perception that teachers in this study often had incomplete perceptions of what the examinations really entailed and involved; and it seemed that they sometimes operated on their own personal assumptions about what different examinations required or how students could be most effectively prepared for them.

\section{CONCLUSION}

This paper has provided empirical evidence documenting teachers' perceptions that examinations generally act as a constraint to the implementation of innovative pedagogy. If Chinese or other governments are determined to promote the implementation of CLT or TBLT, a starting point is to shift examinations in a more communicative or task-based direction because this creates some incentive for teachers to teach more communicatively. This is a helpful first step, but cannot be guaranteed to capture the hearts and minds of the teachers because as we have argued the relationship between an innovation and examinations is a complex one. Teacher beliefs about the relationship between pedagogy and examinations may be even more significant than the nature of the assessment as evidenced by the differing reactions of Jane, as opposed to the other three teachers. Following from this, a further aspect of an integrated approach to assessment and pedagogic change would comprise continuous professional development on the topic of assessment and in relationship to examination-related pedagogy. If more teachers developed, or were supported to develop, their thinking in ways congruent with Jane's perspectives, then CLT would have better prospects for implementation.

Finally, we address briefly some wider implications for the relationship between examinations and student learning. In a globalised educational world which seems to be becoming increasingly assessment-dominated, teachers may become acculturated to the realities of examinations as key performance indicators, so that achievement in examinations (irrespective of whether it leads to genuine long-term learning) becomes a de facto aim of schooling. This is particularly evident in Confucian-heritage societies (Cheng, 2004), but also occurs in other settings. There is a danger that students become good at performing in examinations, but less effective in the kinds of communication, interpersonal and future learning skills demanded by society. Engaging students in productive learning related to preparation for and follow-up to 
examinations, thus becomes a crucial area for further attention (Carless, 2011, forthcoming).

\section{REFERENCES}

Burrows, C. (2004). Washback in classroom-based assessment: A study of washback effect in the Australian adult migrant English Program. In L. Cheng \& Y. Watanabe (Eds.), Washback in language testing: Research contexts and methods (pp. 113-128). Mahwah, NJ: Lawrence Erlbaum.

Carless, D. (2007). The suitability of task-based approaches for secondary schools: Perspectives from Hong Kong. System, 35(4), 595-608.

Carless, D. (2011, forthcoming). From testing to productive student learning: implementing formative assessment in Confucian-heritage settings. New York: Routledge.

Cheng, K.M. (2004). China: Turning the bad master into a good servant. In I. Rosberg (Ed.), Balancing change and tradition in global education reform (p.3-19). Lanham, MD: Scarecrow Education.

Cheng, L. Y. (1999). Changing assessment: Washback on teacher perceptions and actions. Teaching and Teacher Education, 15, 253-271.

Cheng, L. Y., \& Curtis, A. (2004). Washback or backwash: A review of the impact of testing on teaching and learning. In L. Cheng \& Y. Watanabe (Eds.), Washback in language testing: Research contexts and methods (pp. 3-17). Mahwah, NJ: Lawrence Erlbaum.

Cheng, L.Y. \& Qi, L. (2006). Description and examination of the National Matriculation English Test, Language Assessment Quarterly, 3(1), 53-70.

Davison, C. (2007). Views from the chalkface: English language school-based assessment in Hong Kong. Language Assessment Quarterly, 4 (1), 37-68.

Deng, C. R. \& Carless. D (2009). The Communicativeness of Activities in a Taskbased Innovation in Guangdong, China. Asian Journal English Language Teaching,19, 113-134.

Ellis, R. (2003). Task-based language learning and teaching. Oxford: Oxford University Press.

Erlandson, D., Harris, E., Skipper, B., \& Allen, S. (1993). Doing naturalistic inquiry: A guide to methods. Newbury Park: Sage.

Evans, S. (1996). The context of English language education: The case of Hong Kong. RELC Journal, 27(2), 30-55.

Howatt, A. (1984). A history of language teaching. Oxford: Oxford University Press.

$\mathrm{Hu}, \mathrm{G}$. W. (2002). Potential cultural resistance to pedagogical imports: The case of CLT in China. Language, Culture and Curriculum, 15(2), 93-105.

Hu, G. W. (2005a). Contextual influences on instructional practices: A Chinese case for an ecological approach to ELT. TESOL Quarterly, 39(4), 635-660.

Hu, G. W. (2005b). English language education in China: Policies, progress, and problems. Language Policy, 4(1), 5-24. 
Jin, L., \& Cortazzi, M. (2002). English language teaching in China: A bridge to the future. Asia Pacific Journal of Education, 22(2), 53-64.

Leung, Y. M. (1991) Curriculum development in the People's Republic of China. In C.Marsh \& P. Morris (Eds.), Curriculum development in East Asia. London: Falmer Press.

Li, D. (1998). “It's always more difficult than you plan and imagine.” Teachers' perceived difficulties in introducing the communicative approach in South Korea. TESOL Quarterly, 32(4), 677-697.

Littlewood, W. (2004). The task-based approach: Some questions and suggestions. ELT Journal, 58(4), 319-326.

Littlewood, W. (2007). Communicative and task-based language teaching in East Asian classrooms. Language Teaching, 40(2), 243-249.

Li, X. (1984). In defence of the communicative approach. ELT Journal, 38(1), 2-13.

Luk, J. (2010). Talking to score: impression management in L2 Oral Assessment and the Co-construction of a Test Discourse Genre. Language Assessment Quarterly, 7, (1), 25-53.

Miles, M. \& Huberman, A. (1994). Qualitative data analysis: An expanded sourcebook. Thousand Oaks, CA: Sage.

Nunan, D. (2003). The impact of English as a global language on educational policies and practices in the Asia-Pacific region. TESOL Quarterly, 37, 589-613.

O’Donnell, K. (2005). Japanese secondary English teachers: Negotiation of educational roles in the face of curriculum reform. Language, culture and curriculum, 18(3), 300-315.

Ouyang, H. H. (2000). One-way ticket: a story of an innovative teacher in mainland China. Anthropology and Education Quarterly, 31(4), 397-425.

Patton, M. Q. (1990). Qualitative evaluation and research methods. (2nd edition) London: Sage

PEP (2001). Ying Yu Ke Cheng Biao Zhun (English Curriculum Standards). Beijing: Renmin Jiaoyu Chubanshe.

Qi, L. (2005). Stakeholders' conflicting aims undermine the washback function of a high-stakes test. Language Testing, 22 (2), 142-173.

Qi, L. (2007). Is testing an efficient agent for pedagogical change? Examining the intended washback of the writing task in a high-stakes English test in China. Assessment in Education, 14(1), 51-74.

Samimy, K. K., \& Kobayashi, C. (2004). Toward the development of intercultural communicative competence: Theoretical and pedagogical implications for Japanese English teachers. JALT Journal, 26(2), 245-261.

Shohamy, E. (2001). The power of tests: A critical perspective on the use of language tests. Harlow: Longman.

Turner, Y., \& Acker, A. (2002). Education in the new China: shaping ideas at work. Aldershot: Ashgate Publishing Company.

Wall, D. (2000). The impact of high-stakes testing on teaching and learning: Can this be predicted or controlled? System, 28, 499-509.

Wall, D. \& Alderson, J. C. (1993). Examining washback: The Sri Lankan impact study, 
Language Testing, 10(4), 41-69.

Wang, Q. (2007). The National Curriculum changes and their effects on English language teaching in the People's Republic of China. In J. Cummins \& C. Davison (Eds.), International handbook of English language teaching (pp. 87105). Boston, MA: Springer Science \& Business Media.

Watanabe, Y. (1996). Does grammar translation come from the entrance examination? Preliminary findings from classroom-based research. Language Testing, 13(3), 318-333.

Watanabe, Y. (2004). Teacher factors mediating washback. In L. Cheng \& Y. Watanabe (Eds.), Washback in language testing: research contexts and methods (pp. 129-146). Mahwah, NJ: Lawrence Erlbaum.

Wedell, M. (2009) Planning for educational change: Putting people and their contexts first. London: Continuum.

Zhang, Y. E. (2005). The implementation of the task-based approach in primary school English language teaching in mainland China. Unpublished doctoral dissertation, University of Hong Kong.

Zheng, X., \& Davison, C. (2008). Changing Pedagogy: Analyzing ELT teachers in China. London: Continuum. 